\title{
Designing an Engineering Message for Non-Metropolitan Community Col- lege Females
}

\section{Dr. Mary R. Anderson-Rowland, Arizona State University}

Mary Anderson-Rowland, Arizona State University MARY R.ANDERSON-ROWLAND is the PI of an NSF STEP grant to work with five non-metropolitan community colleges to produce more engineers, especially female and underrepresented minority engineers. She also directs an Academic Success and Professional Development program, with an emphasis on transfer students. An Associate Professor in Computing, Informatics, and Systems Design Engineering, she was the Associate Dean of Student Affairs in the Ira A. Fulton Schools of Engineering at ASU from 1993-2004. Anderson-Rowland was named a top 5\% teacher in the Fulton Schools of Engineering for 2009-2010. She received WEPAN's Betty Vetter Research Award 2015, the WEPAN President's Award 2014, WEPAN's Engineering Educator Award 2009, ASEE Minorities Award 2006, the SHPE Educator of the Year 2005, and the National Engineering Award in 2003, the highest honor given by AAES. In 2002 she was named the Distinguished Engineering Educator by the Society of Women Engineers. She has over 190 publications primarily in the areas of recruitment and retention of women and underrepresented minority engineering and computer science students. Her awards are based on her mentoring of students, especially women and underrepresented minority students, and her research in the areas of recruitment and retention. A SWE Fellow and ASEE Fellow, she is a frequent speaker on career opportunities and diversity in engineering.

\section{Dr. Armando A. Rodriguez, Arizona State University}

Prior to joining the ASU Electrical Engineering faculty in 1990, Dr. Armando A. Rodriguez worked at MIT, IBM, AT\&T Bell Laboratories and Raytheon Missile Systems. He has also consulted for Eglin Air Force Base, Boeing Defense and Space Systems, Honeywell and NASA. He has published over 200 technical papers in refereed journals and conference proceedings - over 60 with students. He has authored three engineering texts on classical controls, linear systems, and multivariable control. Dr. Rodriguez has given over 70 invited presentations - 13 plenary - at international and national forums, conferences and corporations. Since 1994, he has directed an extensive engineering mentoring-research academic success and professional development (ASAP) program that has served over 500 students. These efforts have been supported by NSF STEP, S-STEM, and CSEM grants as well as industry. Dr. Rodriguez' research interests include: control of nonlinear distributed parameter, and sampled-data systems; modeling, simulation, animation, and real-time control (MoSART) of Flexible Autonomous Machines operating in an uncertain Environment (FAME); design and control of micro-air vehicles (MAVs), control of bio-economic systems, renewable resources, and sustainable development; control of semiconductor, (hypersonic) aerospace, robotic, and low power electronic systems. Recently, he has worked closely with NASA researchers on the design of scramjet-powered hypersonic vehicles. Dr. Rodriguez' honors include: AT\&T Bell Laboratories Fellowship; Boeing A.D. Welliver Fellowship; ASU Engineering Teaching Excellence Award; IEEE International Outstanding Advisor Award; White House Presidential Excellence Award for Science, Mathematics, and Engineering Mentoring; Ralf Yorque Memorial Best Paper Prize. Dr. Rodriguez has also served on various national technical committees and panels. He is currently serving on the following National Academies panels: Survivability and Lethality Analysis, Army Research Laboratory (ARL) Autonomous Systems. Dr. Rodriguez received his Ph.D. in Electrical Engineering from the Massachusetts Institute of Technology in 1990. Personal Web site: http://aar.faculty.asu.edu/ 


\title{
Designing an Engineering Message for Non-Metropolitan Community College Students
}

\begin{abstract}
Based on grounded theory and Social Cognitive Career Theory, the authors have worked with and researched Community College (CC) students for nearly 15 years, with many of the schools being Hispanic Serving Institutions. A major goal is to be able to get engineering and computer science on the career horizon of undecided students. Over several years, surveys have been taken on CC students at five non-metropolitan schools to try to understand what they like or do not like about engineering and at the same time to identify myths and misconceptions that they have about the field. In particular, two CCs were studied and the beliefs about engineering/computer science were contrasted by school, gender, and ethnicity. In addition, the authors looked at females who were interested in engineering and computer science versus females who were not interested and found some major differences.

Results are presented of a new survey of 54 non-metropolitan CC students to help determine what interests them in a presentation to consider a career in engineering and computer science. The moral here is that it is important to get to know the students you are trying to interest in engineering or computer science. One message, however friendly, does not fit all. Community colleges are not all the same. The engineering myths are still alive and well and need to be addressed. Females often have less information about engineering than males. Feedback from presentations to $\mathrm{CC}$ students can be helpful in guiding future efforts to interest CC students in engineering and computer science.
\end{abstract}

This study was sponsored by an NSF STEP grant (\#0856834).

\section{Introduction}

Forty-five percent of all U.S. undergraduates are enrolled in a Community College (CC). ${ }^{1}$ The majority of Native Americans (62\%), Hispanics 57\%), Blacks (52\%), and women (57\%) undergraduate students are enrolled in CCs. ${ }^{1}$ Our research and experience has shown that CC students need to be exposed to engineering and computer science through CC faculty and guest speakers or role models, as well as informed advisors. The non-metropolitan CC often has only a small engineering/computer science program and is often overlooked by larger schools as a recruitment site. An additional challenge is that the non-metropolitan $\mathrm{CC}$ is often many miles away from the college or university seeking to partner with them. Day trips to visit a remote school mean long hours travelling and also mean that it is difficult to take the ideal transfer role model students out of class in order to visit their previous CC.

The CCs with which the authors have worked are predominantly Hispanic Serving Institutions. Their program has a focus on encouraging more females and underrepresented minority students to study engineering and computer science. These students are often first generation students with limited encouragement to go on to college and little advice on how to go about it. They 
usually live in a small town, have not seen many engineers or computer scientists, and are somewhat fearful of living in a "large city." The students are used to being in small classes, know their professors individually, and have free parking. In addition to all of this we have learned through our experience in working and talking with Hispanic students that the Hispanic culture is very protective of their females. While it may be acceptable for a Hispanic young woman to stay at home and attend a CC, it is a quite different scenario to have her go off to a large city and large school, away from her home. Over 25 years ago, a trial program was begun at Arizona State University (ASU) which has become very effective for encouraging and enabling Hispanic young women to attend a large university. This successful program is the Hispanic Mother-Daughter (HMDP) Program, an "early-outreach college preparatory program designed to raise the educational and career aspirations of Arizona middle and high school students. Its goals are to increase the number of first-generation students who complete a bachelor's degree by directly involving families in the education process of students."2 A main driver is that if the mother can experience the campus with her daughter and become familiar with the idea of college, the mother could become an advocate for her daughter to leave home, if need be, to get at least a baccalaureate degree.

A major challenge in trying to talk with non-metropolitan CC students is that many of them have neither engineering nor computer science anywhere in their vision of a career. Many students who attend a $\mathrm{CC}$ do so to save the expense of living away from home and to take advantage of the much lower tuition fees charged by CCs than by colleges and universities. For females and underrepresented minority students, a lack of self-confidence to do engineering or computer science $^{3}$ plus the lack of foreseeable finances to attend a university, may well be enough for them to not consider going on for a Bachelor's degree in these fields.

The authors first worked with local CCs. With the assistance of liaisons at each CC, it was relatively easy to hold "Be an Engineer" workshops for an hour and get an audience of 75 to over 100 students. The event would include engineering projects, a panel of professional engineers, and a panel of engineering students, plus information given by engineering faculty. CC instructors assisted by dismissing a math or science class to allow the students to attend. An incentive is very helpful to get the students to attend such an event since many students do not know much about engineering and computer science. Henceforth, the term ENGR is used to represent both engineering and computer science. When the authors began working with students at non-metropolitan $\mathrm{CCs}$, the "Be an Engineer" event did not work. There usually were not enough math and science classes held at the same time to supply an audience and if the instructor did not stay, the students would tend to leave the event (after getting pizza and a drink).

The authors soon learned that the best way to get our message heard at the non-metropolitan CC was to have a captive classroom as our audience. They were the first engineering professors to visit each of the five rural schools with which they partnered. Essential in the success of this endeavor were passionate, dedicated personnel at the CCs who partnered with them at the university through an NSF STEP grant (\#0856834). At first some instructors were reluctant to give up their limited class time for "outside" speakers. Part of the message was that the students had good instructors at the $\mathrm{CC}$ and that the students should stay at the $\mathrm{CC}$ as long as they can 
take math, science, and engineering courses that will count towards a Bachelor's degree. Usually after a first classroom visit with limited time, the authors were welcomed back to a full class period in which to engage with the $\mathrm{CC}$ students. For more background on these partnerships with CCs please see the several published papers on this topic. ${ }^{3-11}$

\section{Background}

Many students go to a $\mathrm{CC}$ because they are not sure of their major. The thinking is that they can more economically make their decision on a major at the $\mathrm{CC}$ and then when they have decided, they can transfer to a four-year college or a university and earn their Bachelor's degree. From the experience of the authors, about $30 \%$ of the ASU upper division ENGR transfer students decided on their major at the CC. These numbers certainly justify that it should be the mission of a college or university to partner with CCs to help bring in more engineering students to meet the nation's demand.

The U.S. Education Department reports that only $60 \%$ of students entering four-year institutions earn a Bachelor's degree in six years and only $31 \%$ of public community college students go on to complete either an associate or a Bachelor's degree after six years. ${ }^{12}$ As these types of numbers became well-known, there was an emphasis for several years on changing the face of engineering. This included making the Introduction to Engineering courses more interesting and also changing the message about engineering. While students could see doctors and lawyers in beautiful clothes and living in spacious apartments, the main message about engineering was that it was difficult. It was also recognized that many people had no idea of what an engineer did. A Committee on Public Understanding of Engineering Messages published a report, "Changing the Conversation" in $2008 .{ }^{13}$ This publication started a public discussion on the primary idea that engineering needed to be presented in more positive ways, in ways that appealed to females, males, and minority students so that they would be encouraged to consider and choose engineering as their career.

As the authors have seen in their work, many students still have little or no idea of what engineers or computer scientists do. It is difficult to be passionate or even interested in a career about which a person has little or no knowledge. ${ }^{8}$ While there have been conversations and research done on this general subject of engineering messaging, little research has been done on the particular engineering messaging that would be effective for CC students, and in particular, non-metropolitan CC students. The authors are interested in piquing their interest in ENGR and in knowing how to better prepare these students for the transfer to a comprehensive research university.

Zhang and Ozuna ${ }^{14}$ adopted Rendon' ${ }^{15}$ validation theory to explore students' experience in the $\mathrm{CC}$ and concluded that $\mathrm{CC}$ faculty were the most important support of participants' interpersonal validation experiences. In order for this to work for engineering recruitment, $\mathrm{CC}$ students need to be exposed to engineering either through their own faculty, guest speakers, engineering student role models, or informed advisors.

Based on focus groups, Townsend and Wilson ${ }^{16}$ did interesting research on factors to facilitate the success of community college transfer students to a large research university. A major 
finding was that most of these transfer students mainly need someone to "hold their hand for a little bit" and then they would be able to navigate on their own. This research backs the authors' experience; a message with promise of support at the large university can be very welcomed by a potential transfer student.

The four major responsibilities of a university to retain students as determined by Tinto have also played a role in the recruitment and retention approach of the authors: high expectations; academic, social, and financial support; immediate feedback; and involvement. ${ }^{17}$ Transfer students who receive scholarships and participate in this program are expected to go right to graduate school and earn at least a Master's degree in engineering. Through the "Guaranteed 4.0 Plan" learning system, the students are helped with their academics. ${ }^{18}$ The Academic Success and Professional Development class helps the students with networking and working a career fair, and encourages them to become leaders, to be active in student organizations, and to complete research projects, as well as plan their career for ten years past the baccalaureate.

\section{Previous Studies}

Since the authors began working with transfer students in 2002, they have been researching ways to help them become aware of ENGR and to assist with the transfer process. They are interested in knowing how best to get more CC students interested in ENGR. They have worked to make the transfer process smoother for the students and to support them once they transfer. Their goal is to graduate each one of these students in ENGR and, when they graduate, to go right on to graduate school full-time to earn a Master's or Ph.D. degree. The authors have been quite successful in graduating the scholarship students that have been supported with scholarships from the National Science Foundation's S-STEM and STEP programs. In fact, over 95\% of the upper division transfer students graduate, compared to $70 \%$ of the other upper division transfer students. Also, $50 \%$ of the graduating students go right on to graduate school.

By encouraging non-metropolitan CC students to choose ENGR as their major and to transfer to $\mathrm{xxx}$, the number of transfers from these schools has increased from 80 to 178 in the past six years. The research continues on how to better get their attention turned to ENGR. Since fall 2012 the authors have been focusing their research on the message that non-metropolitan CC students are hearing about ENGR. A summary of surveys and their results are recounted in a previous paper. $^{2}$

In $\mathrm{f}$ all 2012 surveys were administered in our five partner non-metropolitan CCs. ${ }^{3}$ Students were first asked if ENGR was their career choice. If the student answered "Yes," they were directed to identify reasons from a list as to why they were interested in ENGR. If the student was not interested in ENGR, they were asked to identify reasons why that was so. The lists on the survey had been built using ground theory by first asking open questions and also talking with students. Students who said they were interested in engineering were asked to identify their top three reasons for being so. From their list of these choices, the top six reasons were identified as: money, like math/science, exciting, many job opportunities, challenging, and want to make a difference. Similarly, the top reasons students were not interested in ENGR were: does not sound interesting to me, not good enough at math, think engineerin56ytg is simply too hard, do not like 
math, not aware of many engineering job opportunities, and I want to work outside, not in an office. For students who said NO to engineering, the largest difference $(p<.025)$ between females and males was that females were less aware of many engineering job opportunities. This result should not be surprising, especially since these students are living in rural areas where there are not a lot of engineering jobs.

Another survey was developed from these results which asked the students degree of belief in statements about engineering. ${ }^{10}$ This survey was given to two non-metropolitan CCs with interesting results. These schools would appear to be similar, both being Hispanic Serving Institutions. In one school there was little difference between the beliefs of the females and males, but large differences between minority and non-minority students. At the other school, there was little difference between the beliefs of the minority and non-minority students, but statistically different results between the females and males. These results show that an engineering message cannot be "one size fits all." It is important to get to know the particular student audience being addressed to make sure that the message will resonate with them, and address their myths and unfounded fears.

\section{Current Study}

The previous surveys were done at the beginning of a class session with students. The authors wanted to know what the students' basic understanding of ENGR was before they heard a talk about engineering. In this study, a survey evaluation was given to the students after they had heard an ENGR presentation for 30-50 minutes. The authors were interested in knowing "what was the most interesting" thing the students heard from the presentation and "what was the most important" thing they heard. The students were also asked if they had heard anything that would increase their possible pursuing of an ENGR degree, and if so, what was that item.

The 54 students who took the survey were primarily in college algebra, Calculus I, and Calculus II classes. There were 22 females and 32 males. There were 14 Hispanic/Latino and 2 African American students. When asked if they were interested in engineering or computer science as a career, 33 answered Yes, 6 answered No, and 15 were undecided. The students were then asked an open-ended question, "What was the most interesting thing that you heard today?" Table I gives these results.

The responses are given in the general order of number of students who responded with that answer. It is clear that, even in a group of only 54 students, many different items were "the most interesting." The fact that there are lots of opportunities in engineering and that engineering ties in with many different fields were the most repeated observations. The other popular topics were on cloaking devices and a Mach 10 aircraft. Other students were interested in learning more about the majors, a Master's degree, and the support given at our university for transfer students. Although we identified the responses by gender and ethnicity, the sample sizes are too small to discern any real patterns, other than that the topics seemed to be generally of interest to all groups. 
Table I. Responses to the question, "What was the most interesting thing that you heard today?"

\begin{tabular}{|l|l|l|l|l|l|}
\hline What was the most interesting thing you heard about engineering/computer science today? \\
\hline Item & Female & Male & Minority & $\begin{array}{l}\text { Non- } \\
\text { Minority }\end{array}$ & Total \\
\hline A lot of career fields can tie in with engineering & 1 & 4 & 2 & 3 & 5 \\
\hline There are a lot of fields in engineering & 3 & 2 & 1 & 4 & 5 \\
\hline You can make things invisible (cloaking) & 2 & 3 & 2 & 3 & 5 \\
\hline The x-43 going Mach 10 & 1 & 4 & & 5 & 5 \\
\hline How big the job market is for engineering & 2 & 2 & 3 & 1 & 4 \\
\hline That people are growing organs & 2 & 1 & 1 & 2 & 3 \\
\hline The man's nose growing on his forehead & 2 & & 1 & 1 & 2 \\
\hline Engineering is applied to everything in life & 1 & 1 & & 2 & 2 \\
\hline Bird wing style airplanes being researched at ASU & & 2 & 1 & 1 & 2 \\
\hline Industrial engineering advances & & 2 & & 2 & 2 \\
\hline $\begin{array}{l}\text { Higher education/Master's degree=more } \\
\text { interesting/challenging problems }\end{array}$ & & 2 & & 2 & 2 \\
\hline The advances in biomedical engineering & 1 & 1 & 1 & 1 & 2 \\
\hline Engineers really help people & 1 & & 1 & & 1 \\
\hline Engineers come up with cool things & 1 & & 1 & & 1 \\
\hline Everything; Idn't know anything before today & 1 & & 1 & & 1 \\
\hline How energetic the male speaker is & & 1 & & 1 & 1 \\
\hline The program xxx has to help students & & 1 & & 1 & 1 \\
\hline Didn't talk much about computer science & & 1 & & 1 & 1 \\
\hline Civil engineering also includes environ. engr & & 1 & & 1 & 1 \\
\hline The 3D model of heart being used by surgeons & 1 & & & 1 & 1 \\
\hline The amount of projects I will be able to work on & 1 & & 1 & & 1 \\
\hline Progression/importance of computer science & & 1 & & 1 & 1 \\
\hline The details of the JIMO project & & 1 & & 1 & 1 \\
\hline Lots of scholarships at xxx & 1 & & & 1 & 1 \\
\hline Lots of sciences are combined in engineering & 1 & 30 & 16 & 36 & 1 \\
\hline Totals & & & 52 \\
\hline
\end{tabular}

The results to the question, "What was the most important thing you heard about engineering/computer science today?" are shown in Table II. The responses in this table are arranged by category to give a better picture of the student impressions. The first 6 responses all had to do with good job opportunities and success after college. Responses 7-9 reflected the importance of engineering in helping people and in everyday life. Responses 10-12 focused on engineering majors. Responses 13-17 centered on academic affairs, while the support program and scholarships at the research school were contained in responses 18-20. A potpourri of responses complete the list. There do not seem to be any obvious trends by gender or ethnicity, other than that $25 \%$ of the females thought the most important item they heard was about the broad number of jobs and careers available to ENGR. 
Table II. What was the most important thing that you heard today about engineering and computer science by Gender and Ethnicity

\begin{tabular}{|c|c|c|c|c|c|c|}
\hline \multirow[b]{2}{*}{ \# } & \multicolumn{6}{|c|}{ What was the most important thing you heard about engineering/computer science today? } \\
\hline & Category & Female & Male & $\begin{array}{l}\text { Minor } \\
\text { ity }\end{array}$ & $\begin{array}{l}\text { Non- } \\
\text { Minority }\end{array}$ & Total \\
\hline & Jobs/Career & & & & & \\
\hline 1 & $\begin{array}{l}\text { How big the job market is/lots of job opportunities } \\
\text { available }\end{array}$ & 5 & 2 & 2 & 5 & 7 \\
\hline 2 & A lot of chances to get a job and create things & & 2 & & 2 & 2 \\
\hline 3 & $\begin{array}{l}\text { Engineers have many opportunities to create a } \\
\text { sound career/good field to go in }\end{array}$ & 1 & 1 & & 2 & 2 \\
\hline 4 & The types of jobs that engineers do & 1 & 1 & & 2 & 2 \\
\hline 5 & Any type of engineering can help with other fields & & 1 & 1 & & 1 \\
\hline 6 & Success after college & & 1 & 1 & & 1 \\
\hline & Help people/Important in everyday life & & & & & \\
\hline 7 & $\begin{array}{l}\text { You can help people with engineering, such as grow } \\
\text { organs/improve society }\end{array}$ & 1 & 2 & 2 & 1 & 3 \\
\hline 8 & How important it is in everyday life & 1 & & 1 & & 1 \\
\hline 9 & $\begin{array}{l}\text { Engineering is part of the future and builds the } \\
\text { future }\end{array}$ & & 1 & & 1 & 1 \\
\hline & Interest in individual majors & & & & & \\
\hline 10 & Biomedical is a growing field/interesting, valuable & 2 & & 2 & & 2 \\
\hline 11 & $\begin{array}{l}\text { Electrical engineering is very broad, like systems } \\
\text { engr. }\end{array}$ & & 1 & & 1 & 1 \\
\hline 12 & I could do environmental engineering & & 1 & & 1 & 1 \\
\hline & Academic Information & & & & & \\
\hline 13 & $\begin{array}{l}\text { Master's degree in engineering, 4+1/important for } \\
\text { expanding career }\end{array}$ & 1 & 2 & 2 & 1 & 3 \\
\hline 14 & Take most of your classes at the community college & 1 & & & 1 & 1 \\
\hline 15 & My current major can easily be switched to engr. & 1 & & 1 & & 1 \\
\hline 16 & I should take biomed while I take pre-med & & 1 & & 1 & 1 \\
\hline 17 & Engineering degrees are more in depth than others & 1 & & & 1 & 1 \\
\hline & Financial Support & & & & & \\
\hline 18 & The support xxx has/help available to engr. students & 1 & 2 & 1 & 2 & 3 \\
\hline 19 & Scholarships for engineering majors & 2 & 1 & & 3 & 3 \\
\hline 20 & $\begin{array}{l}\text { The statistics regarding the GPA and graduation rate } \\
\text { for scholarship recipients at } x x x\end{array}$ & & 1 & & 1 & 1 \\
\hline & Exciting, New Ideas & & & & & \\
\hline 21 & $\begin{array}{l}\text { Orbital reentry speeds can melt steel, spread } \\
\text { through aircraft and cause an explosion }\end{array}$ & & 1 & & 1 & 1 \\
\hline 22 & $\begin{array}{l}\text { A test can now determine cancer from a single drop } \\
\text { of blood }\end{array}$ & 1 & & & 1 & 1 \\
\hline 23 & USA needs engineers & & 1 & & 1 & 1 \\
\hline 24 & Passion outweighs brains & 1 & & 1 & & 1 \\
\hline 25 & It'll make you crazy & & 1 & & 1 & 1 \\
\hline & Totals & 20 & 23 & 14 & 29 & 43 \\
\hline
\end{tabular}


The results to the third major question are shown in Table III.

Table III. Topics identified by 33 students which have caused them to give more consideration to engineering and computer science as a career.

\begin{tabular}{|c|c|}
\hline \multicolumn{2}{|c|}{$\begin{array}{l}\text { Did you hear anything today that will cause you to consider an engineering/computer science } \\
\text { career more carefully? If yes, what was it? }\end{array}$} \\
\hline & Abundance and Variety of Engineering Jobs \\
\hline 1 & Engineering is a growing field and a Master's degree is much needed \\
\hline 2 & The opportunities being offered after college for engineers \\
\hline 3 & Opportunities \\
\hline 4 & Things you can help create and all the opportunities that you have with engineering \\
\hline 5 & All the options \\
\hline 6 & The job opportunities in the computer science field \\
\hline 7 & The things I wish to do are very well paid and in high demand \\
\hline 8 & $\mathbf{\$ \$}$ \\
\hline 9 & Money, vacations \\
\hline 10 & Its practical in the future \\
\hline 11 & Vacations \\
\hline 12 & Different projects \\
\hline \multirow[t]{2}{*}{13} & Even banks today are in need of engineers \\
\hline & Engineering Majors \\
\hline 14 & Many classes in biomed are the same as premed \\
\hline 15 & Industrial Engineering sounded interesting \\
\hline 16 & Business and engineering are related \\
\hline 17 & More information on my engineering major \\
\hline 18 & Biomedical engineering, I love the idea of fixing people \\
\hline 19 & The advances in nerves in biomedical engineering \\
\hline 20 & Knowledge of the job environmental engineering \\
\hline 21 & You can still be in the health field as an engineer \\
\hline 22 & Growing organs \\
\hline \multirow[t]{2}{*}{23} & Sound waves \\
\hline & Financial Support \\
\hline 24 & Scholarships/Internships \\
\hline 25 & Stories about financially less able students succeeding \\
\hline \multirow[t]{2}{*}{26} & The projects being worked on at $\mathbf{x x x}$ \\
\hline & Challenging Career \\
\hline \multirow[t]{2}{*}{27} & How engineering careers are the most challenging yet rewarding fields \\
\hline & Good to Consider Job Availability \\
\hline \multirow[t]{2}{*}{28} & The lack of jobs for physicists \\
\hline & Reinforcement \\
\hline 29 & Reassuring information that encourages me to continue in my engineering path \\
\hline \multirow[t]{2}{*}{30} & I heard interesting facts about a career I was already considering \\
\hline & Inspired \\
\hline 31 & Inspiring talk; I really want to help \\
\hline 32 & Everything \\
\hline
\end{tabular}


The third major question on the survey was, "Did you hear anything today that will cause you to consider an engineering/computer science career more carefully? If yes, what was it?" Of the 54 students, 35 (64.8\%) said Yes and 18 (33.3\%) said No with one student not answering.

The responses in Table III were arranged by topic. It is clear that the main topic which caught the students' attention are the abundance and variety of jobs in the ENGR area. These items, of course, translate to money and security for the students. The next largest group dealt with more information on specific majors. A good example is the student who apparently discovered that if he wanted to work with the environment, he could do so as an engineer. The next topic mentioned was the scholarships, support program, and abundance of projects that were available at ASU. Two of the students appreciated the reassuring information about ENGR since they were already considering these fields.

\section{Results}

The results of this survey indicate that the students found the presentation interesting, important, and impactful. The variety of responses implies that more than a simple message with a few points is needed to interest most of the audience. With nearly $65 \%$ of the students reporting that they would now consider ENGR more carefully based on what they heard, the authors conclude that their long trip to this campus was well-worth their time.

\section{Conclusion}

The authors have been travelling and speaking to students in CCs for about seven years. They continue to interact with students who after their visit decide to choose ENGR as their major and to transfer to ASU. When these trips first began to visit the five non-metropolitan schools, there were 80 transfer students total at ASU majoring in ENGR. One school did not have an engineering department. In six years the number of ENGR transfers from these schools have increased to 178. All five schools now have engineering as a focus area for their students. Obviously, retention and graduation of these transfer students is very important to the authors. Sixty percent of the NSF scholarships have gone to females and underrepresented minority students, all with unmet financial need. Many of these are first generation students. These are students who are at risk. On average, upper division transfer students in ENGR at ASU have a $70 \%$ graduate rate (64\% for females). The program upper division transfer scholarship students have graduated at a $95 \%$ rate. In addition, $50 \%$ of these graduates have gone right on to graduate school in ENGR. Several of these students are now pursuing a Ph.D. degree in engineering. A national estimate is that less than $20 \%$ of graduating engineering students go right on to graduate school and that percentage is lower than $15 \%$ at ASU for transfer students not in the scholarship program.

In spite of the success of the program, the authors continue to work to improve the program. A most important first step to increasing the number of transfer students in ENGR is to get CC students interested in ENGR and to at least consider ENGR as a career. The authors encourage others who are working with CC students to try to determine the profile of their students. Each school is unique. One size does not fit all. This takes effort, but it is well worth it. 


\section{Acknowledgment}

Thanks goes to Kelly Wilmink for putting the data into an EXCEL sheet for easier analysis.

\section{References}

1. 2015 Community College Fast Facts, American Association of Community Colleges, http://www.aacc.nche.edu/AboutCC/Pages/fastfactsfactsheet.aspx

2. https://eoss.asu.edu/hmdp

3. Anderson-Rowland, M.R., Rodriguez, A.A., and Grierson, A.E. (2013). "Why Some Community College Students Choose Engineering and Some Don't," ASEE Annual Conference and Exposition, Conference Proceedings, Atlanta, GA.

4. Anderson-Rowland, M.R. and VanIngen-Dunn, C. (2007). "Encouraging Transfer Students to Pursue a Bachelor's Degree in Engineering and Computer Science," ASEE Annual Conference and Exposition, Conference Proceedings.

5. Anderson-Rowland, M.R., Rodriguez, A.A., and Grierson, A.E. (2011). "Making a Difference: How to Recruit More Community College Women and Underrepresented Minority Students Into Engineering and Computer Science," ASEE Annual Conference and Exposition, Conference Proceedings.

6. Anderson-Rowland, M.R., Rodriguez, A.A., and Grierson, A.E. (2012). "Determining the Community College Audience," ASEE Annual Conference and Exposition, Conference Proceedings.

7. -Rowland, M.R. and Rodriguez, A.A. (2015) "Getting the Attention of Underrepresented Minority Community College Students to Consider Engineering as a Career," 2015 Proceedings of the Frontiers in Education, El Paso, TX, 7 pages.

8. Anderson-Rowland, M.R. (2013). "When Transfer Students Choose Engineering Majors and Why," Women in Engineering Pro-Active Network (WEPAN) Proceedings.

9. Anderson-Rowland, M.R., Rodriguez, A.A., and Grierson, A.E. (2014) "Determining Student Beliefs about Engineering," 2014 Proceedings of Frontiers in Education, Madrid, Spain.

10. Anderson-Rowland, M.R., Rodriguez, A.A., and Grierson, A.E. (2015). "METSTEP after Six Years," ASEE Annual Engineering Conference and Exposition, Conference Proceedings, Seattle, WA, 7 pages.

11. Anderson-Rowland, M.R., Rodriguez, A.A., and Grierson, A.E. (2015) "Discovering How to Get Engineering and Computer Science on the Radar of Community College Students," ASEE Annual Conference and Exposition, Conference Proceedings.

12. Roach, R. (2009). "The Community College Transfer Challenge," Diverse Issues in Higher Education, 26.7 (May 14, 2009) 14-15.

13. Committee on Public Understanding of Engineering Messages, National Academy of Engineering. (2008). Changing the Conversation: Messages for Improving Public Understanding of Engineering. The National Academy Press, Washington, D.C.

14. Zhang, Y. \& Ozuna, T. (2015). "Pathways to Engineering: The Validation Experiences of Transfer Students," Community College Journal of Research and Practice, 39:355-365, 2015.

15. Rendon, L.L. (1994). "Validating culturally diverse students: Toward a new model of learning and student development," Innovative Higher Education, 19(1), 33-51.

16. Townsend, B.K. and Wilson, K.B. (2006). "A Hand Hold for a Little Bit,: Factors Facilitating the Success of Community College Transfer Students to a Large Research University," Journal of College Student Development, Volume 47, Number 4, July/August, 2006, pp. 439-456 (Article)

17. Tinto, V. C. (2012). "Completing college: rethinking institutional action," The University of Chicago Press, Chicago and London.

18. Johnson, D.O. and Chen, Y.C. (2004). “Guaranteed 4.0 Plan, ” JCYC Studio, Dallas, Texas. 
